\title{
Petrogenesis of Magnesian High-K Granitoids From Bitkine (Centre Chad Massif): Major and Trace Elements Constraints
}

\author{
Mbaihoudou Diontar, Jean Claude Doumnang, Maurice Kwékam, Zagalo Al-hadj Hamid, \\ Armand Kagou Dongmo, Julios Efon Awoum, Jules Tcheumenak Kouémo
}

\section{ABSTRACT}

Major and trace element data were used to constrain the nature and origin of the Bitkine gabbro-diorite magma.The gabbro-diorites of Bitkine within the Guéra Massif, and associated microgranular enclaves consist of plagioclase, k-feldspar, clinopyroxene, amphibole, biotite and quartz. Gabbro-diorites and enclaves are basic to intermediate rocks. They are high-K magnesian calcalkaline with shoshonite affinity. $\Sigma$ REE range from 132 to $436 \mathrm{ppm}$ in gabbrodiorites, while they are from 134 to $207 \mathrm{ppm}$ in enclaves. LREE are weakly enriched compared to $\mathrm{HREE}(\mathrm{La} / \mathrm{Yb})_{\mathrm{N}}=(12.23-41.40)$ and $(6.20-31.86)$ respectively in gabbro-diorites and enclaves. These rocks show a weak negative anomaly in europium $\left(\mathrm{Eu} / \mathrm{Eu}^{*}=\mathbf{0 . 7 8 - 1 . 0 7}\right)$. They are rich in $\mathrm{Ba}$ and $\mathrm{Sr}$, and show negative anomalies in $\mathrm{Nb}$, Ta and $\mathrm{Ti}$. The $\mathrm{Nb} / \mathrm{Ta}, \mathrm{Rb} / \mathrm{Cs}$ and $\mathrm{Ba} / \mathrm{Nb}$ ratios of the Bitkine gabbro-diorites and their enclaves indicate that they are derived from mantle magma modified by subducted fluids. This magma during its evolution by fractional crystallization was contaminated by crustal materials.

Keywords: Bitkine, Gabbro-diorite, High-k magnesian, Enriched mantle, Fractional crystallization.

Published Online: October 9,2020

ISSN: $2684-446 \mathrm{X}$

DOI :10.24018/ejgeo.2020.1.5.78

\section{Diontar}

Laboratoire de Géologie, Département de Génie Géologique, Université Polytechnique de Mongo, Cameroon.

(e-mail: diontar.2004@yahoo.fr)

J. C. Doumnang

Laboratoire de Géologie, Géomorphologie et Télédétection (LGGT), Université de N'Djamena, Cameroon.

(e-mail: jdoumnang2002@yahoo.fr) M. Kwékam*

Laboratoire de Géologie de l'Environnement (LAGE), Faculté des Sciences, Université de Dschang, Cameroon.

(e-mail: maurice.kwekam ${ }^{\circledR}$ univdschang.org)

Z. Al-hadji Hamid

Université des Sciences et de Technologie d'Ati (Chad); LAGE, Faculté des Sciences, Université de Dschang, Cameroon.

(e-mail: filsbenbadour@yahoo.fr)

A. Kagou Dongmo

Laboratoire de Géologie de l'Environnement (LAGE), Faculté des Sciences, Université de Dschang, Cameroon.

(e-mail: kagoudongmo@yahoo.fr)

J. Efon Awoum.

Laboratoire de Géologie de

l'Environnement (LAGE), Faculté des

Sciences, Université de Dschang, Cameroon.

(e-mail: juliosefon9@gmail.com)

J. Tcheumenak Kouémo

Department of Earth Sciences, Faculty of Sciences, University of Douala, Cameroon.

(e-mail: tcheumenak2@gmail.com)

*Corresponding Author

\section{INTRODUCTION}

The Guéra Massif is one of the smallest massifs in Chad within the Sahara Metacraton (Fig. 1), [1]-[2]. It consists of 90\% granitoids [3]-[4]. These granitoids are characterised by petrographic diversity. They consist of gabbros, diorites, granodiorites, granites and charnockites [5]-[7]. These granitoids are believed to result from intense magmatic activity during the pan-African orogeny. During this orogeny, the blocks assembled to form Gondwana. The Guéra massif is wedged between the Chad craton, the Darfur block (in the Sahara metacraton) and the Congo craton (Fig. 1). It is separated from the Chad craton by the gravity anomaly [8]. This position of the Guéra massif is very interesting for the 
understanding of crustal evolution and the crustal-mantle relationship during the pan-African orogeny in central Chad. Thus, field and geochemical data of the major elements of the Bitkine gabbro-diorites and their enclaves are presented in this paper in order to determine the nature and origin of their parent magmas. These preliminary results will certainly contribute to the advancement of knowledge on the petrogenetic and geodynamic processes of the granitoids of the Central Chad Massif (Guéra Massif).
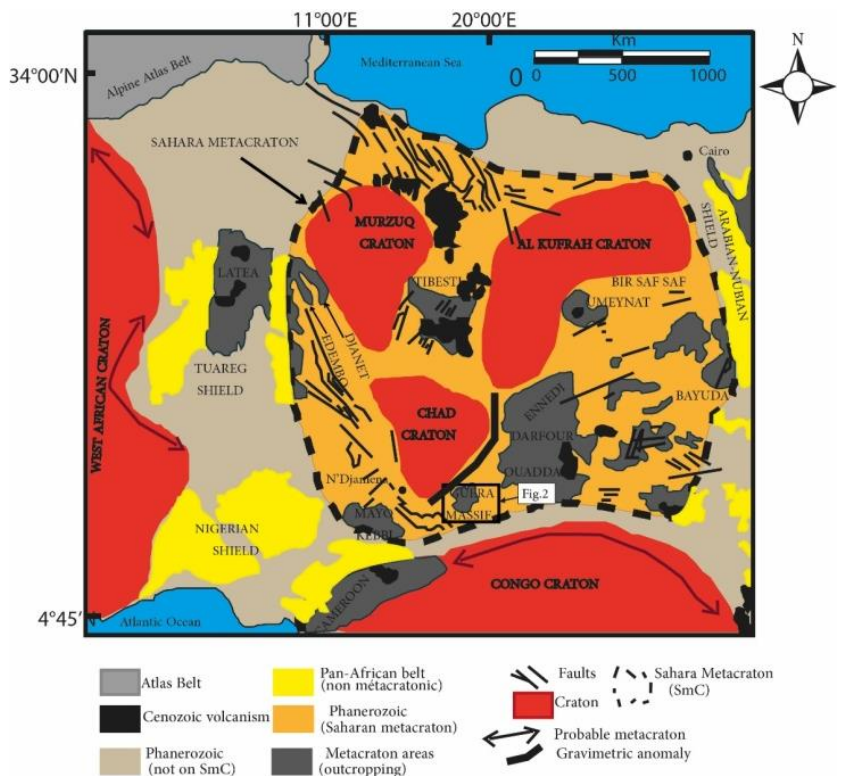

Fig. 1. Geological sketch map of west-central Africa with cratonic areas and the Pan-African-Brasiliano provinces of the Pan-Gondwana belt in a Pangea reconstruction; modified from [1], after [2].

\section{GeOlogicAl Setting}

The Precambrian formations in Chad are made up of six blocks: the Mayo-Kebbi Massif in the South-West, the Ouaddai Massif in the East, the Yadé Massif in the South, the Tibesti Massif in the North and the Guéra Massif in the Centre. These formations are largely covered by sedimentary rocks.

The Guéra Massif (Central Chad Massif) located on the southern edge of the Sahara Metacraton, is one of the least studied formations because of the scarcity of rock outcrops. It consists of magmatic rocks and metamorphic rocks (Fig. 2). These rocks were laid down during the collision between the Congo-Sao Francisco Craton and the Sahara Metacraton. The Bitkine region consists of gabbro-diorites, amphibole and biotite granites, biotite granites, charnockites and orthogneiss (Fig. 3). Recent work by [7] showed that magmatism in the Guéra Massif was active for $50 \mathrm{Ma}$ in the interval $595 \mathrm{Ma} \sim 545 \mathrm{Ma}$. The U-Th-Pb ages obtained on individual zircons range from $1900 \mathrm{Ma}$ to $580 \mathrm{Ma}$, indicating crustal recycling during pan-African orogeny. The oldest granites $(595 \pm 8 \mathrm{Ma}, 589 \pm 6 \mathrm{Ma})$ are metaluminous to peraluminous, magnesian, alkaline to calcic-alkaline [9]. Young granites $(\leq 570 \mathrm{Ma})$ are peraluminous, ferriferous, alkaline-calcic and post-collisional [10]-[14]. [15] distinguished between collisional and post-collisional granites. Post-collisional granites belong to two generations. The first generation is represented by hornblende and biotite granites dated at $595 \mathrm{Ma}$. These are volcanic arc granites and derive from the partial melting of a mantle wedge modified by subduction [7]. The second generation consists of biotite granites dated at $590 \mathrm{Ma}$, these are post-collisional granites. The post-collisional granites are emplaced during crustal relaxation after the oblique collision between the Congo-Saô Francisco craton and the Sahara Metacraton ([16]-[17]). Granites dated at $560 \mathrm{Ma}$ are emplaced during the second period of post-collisional magmatism after an episode of crustal thinning ([16], [17])

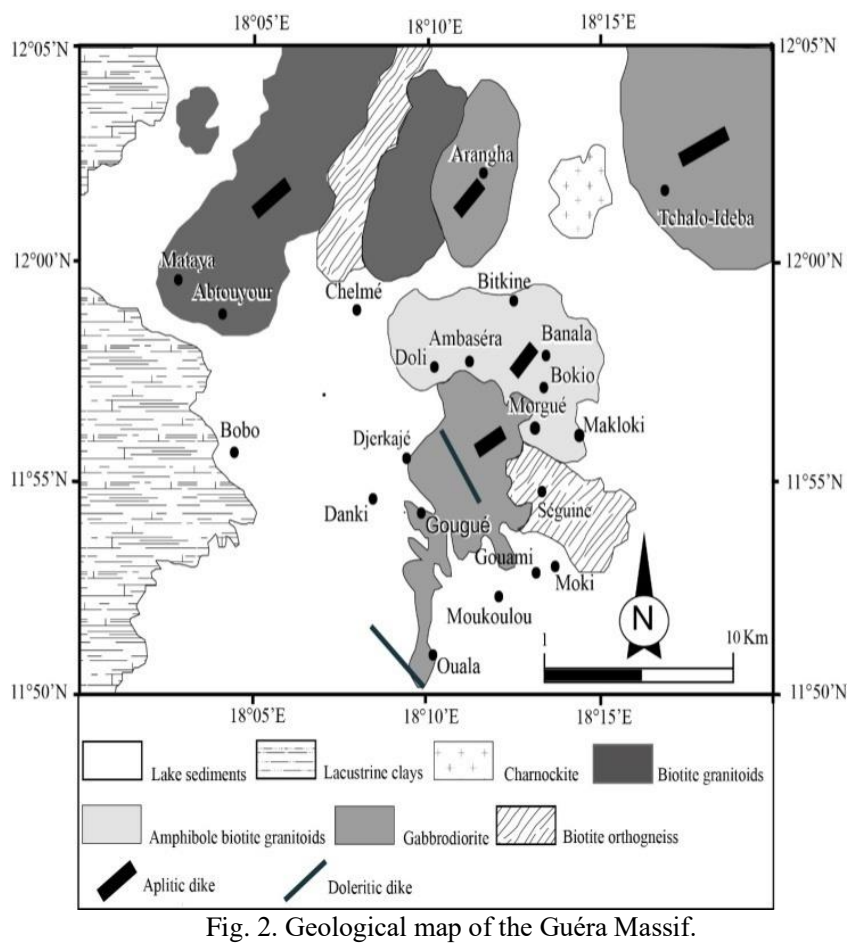

\section{Petrography}

The gabbro-diorite outcrops in the form of slabs (Fig. 3a), metric to decametric blocks in plains and watercourses in the NE-SW to ENE-WSW direction (Fig. 3). It also occurs in basic microgranular enclaves in granites (Fig. 3c). The microgranular enclaves are either scattered or grouped in swarms or magmatic breccias patched by granitic fluids (Fig. $3 \mathrm{~d})$. The size of the enclaves varies from $15 \mathrm{~cm}$ centimeters to $30 \mathrm{~cm}$. The major axes of the enclaves are preferentially oriented in the N-S to NE-SW direction. In the field, gabbrodiorite is a dark grey to medium to coarse-grained rock. The size of the minerals varies from millimeters to centimeters. It has the same composition as the enclaves. The enclaves are medium to fine grained. They consist of plagioclase, alkaline feldspar, quartz, clinopyroxene, amphibole and biotite Zircon, apatite and iron oxides are the accessory minerals. Plagioclase is automorphic to subautomorphic and occurs as large, often intersecting slats. It has albite polysynthetic twin. Plagioclase phenocrysts contain inclusions of small clinopyroxene crystals. Alkaline feldspar consists essentially of orthose. Orthose is present in the form of automorphic or subautomorphic phenocrysts and Carlsbad-twin. Some crystals are sometimes resorbed and appear in rounded or ovoid form. Clinoyroxene and amphibole crystals are arranged along the edges of resorbed plagioclase phenocrysts. 
The amphibole is in the form of automorphic to subautomorphic phenocrysts. The size of the crystals varies from 0.3 to $0.5 \mathrm{~mm}$. Clinopyroxene occurs as crystals in automorphic basal sections with two cleavages. It is automorphic to subautomorphic and less than $2 \mathrm{~mm}$ in size. It sometimes appears as an inclusion in plagioclase and biotite. Biotite occurs in the form of flakes and lamellae varying in size from 2 to $3 \mathrm{~mm}$. Biotite flakes frequently crystallize around plagioclase and clinopyroxene phenocrysts. Quartz is rare and interstitial and crystallizes as fine to medium grains around alkaline feldspar. Apatite and zircon are usually included in amphibole and biotite.
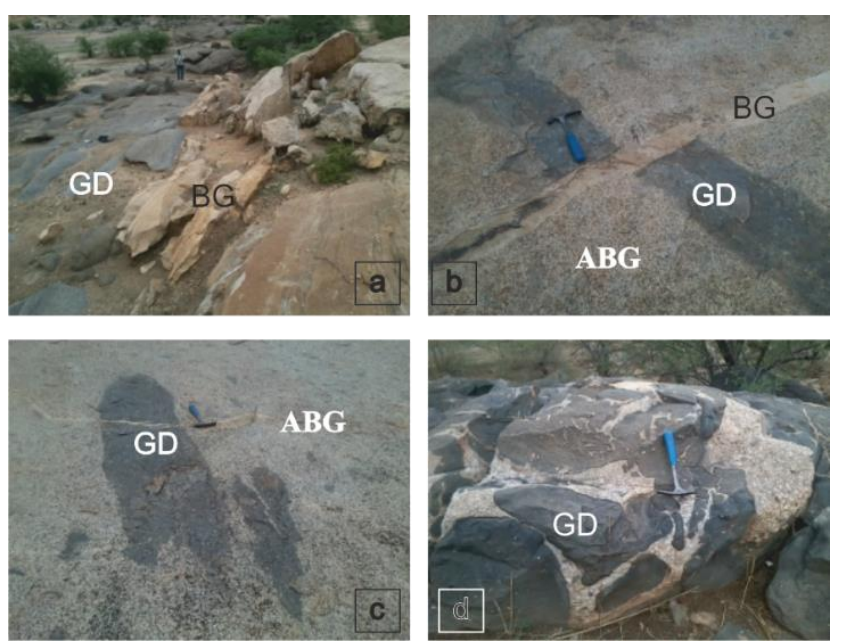

Fig. 3. Field observations, (a) Gabbro-diorite slab outcrop (GD) in contact with biotite granite (BG), (b) Gabbro-diorite dyke (GD) intersecting the amphibole-biotite granite (ABG), and taken up by a biotite granite vein

(BG), (c) Elongated microgranular enclave (GD) with one extremity

destabilised in swarms of small enclaves, in amphibole-biotite granite (ABG), (d)Magmatic breccia with gabbro-diorite blocks (GD) clogged by the granitic melt.

\section{ANALYTICAL TECHNIQUES}

Geochemical analyses of major, trace and rare earth elements were performed at ACTLABS (Activation Laboratories) Ontario (CANADA). Major and some trace elements (Sc, V, Cr, Co, Ni, Zn, Ga, Rb, Sr, Zr, and Ba) are analyzed by ICP-AES ("inductively coupled plasma Atomic Emission"). The other trace elements are analyzed by ICPMS ("Inductively Coupled Plasma Mass Spectrometer") using the VG-Plasma Quad STE ICP spectrometer. The uncertainties of analysis are $1 \%$ for the concentration of the major elements (with the exception of $\mathrm{Fe}$ and $\mathrm{Na}$, which is $2 \%$ ), and around $5 \%$ for the concentration of trace elements. The accuracy of analyses for rare earths, compared to the JB3 and JA2 standard, is between $15 \%$ and $20 \%$ for $\mathrm{Nb}$ and $\mathrm{Ta}$ and less than $10 \%$ for the concentrations of the other elements.

\section{RESUlts}

The samples analysed show a chemical composition of basic to intermediate rocks $\left(\mathrm{SiO}_{2}=48.60-61.35 \%\right)$. They are monzogabbro, monzodiorite, diorite, monzonite and syenite in composition (Fig. 4a). They are subalkaline $\left(\mathrm{Na}_{2} \mathrm{O}+\mathrm{K}_{2} \mathrm{O}\right.$ $=5-10.50 \%$ ), calc-alkaline strongly potassic to shoshonitic rocks $\left(\mathrm{K}_{2} \mathrm{O} / \mathrm{Na}_{2} \mathrm{O}=0.61-3.46\right.$, Fig.4b $)$ [18]-[20]. These are metaluminous granitoids $(\mathrm{A} / \mathrm{CNk}=0.59-0.96)$. They are alkali-alkaline to calcic-alkaline and magnesian $((\mathrm{FeOt} / \mathrm{FeOt}$ $+\mathrm{MgO}=0.51-0.72$, in gabbro-diorites) and (0.42-0.85, in enclaves), Fig.4c and 4d, [21]. The elements $\mathrm{MgO}, \mathrm{CaO}, \mathrm{TiO}_{2}$ and $\mathrm{P}_{2} \mathrm{O}_{5}$ decrease with increasing $\mathrm{SiO}_{2}$ content while $\mathrm{Al}_{2} \mathrm{O}_{3}$ element shows a positive correlation with $\mathrm{SiO}_{2}$ (Fig. 5). The behavior of $\mathrm{Al}_{2} \mathrm{O}_{3}$ compared to $\mathrm{CaO}$ and $\mathrm{MgO}$ suggests that magma differentiation is controlled by the crystallization of magnesian calcareous minerals such as clinopyroxene.
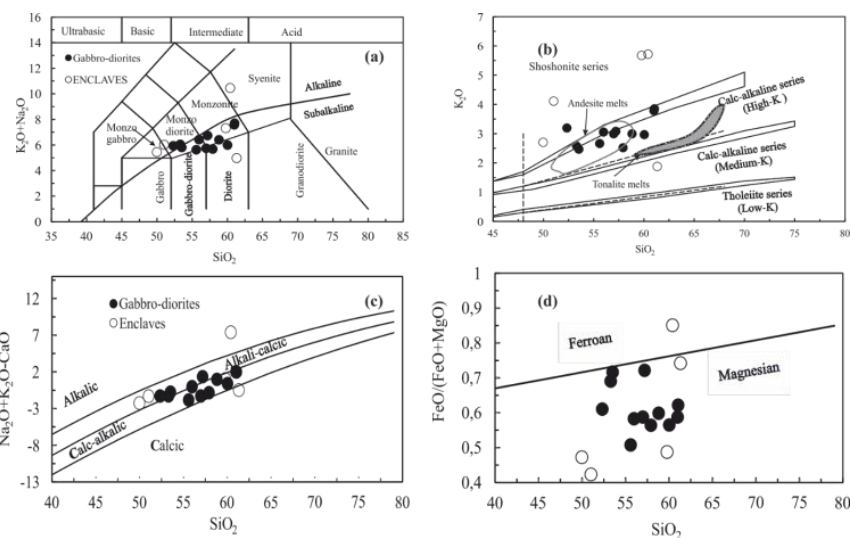

Fig. 4. Geochemical characterization of Bitkine's gabbro-diorites, (a) $\mathrm{K} 2 \mathrm{O}+\mathrm{Na} 2 \mathrm{O}$ vs $\mathrm{SiO} 2$ de (b)K2O vs SiO2diagram, field boundaries ([18][19]), fields of andesite and tonalite melts are from [20], (c) Mali diagram and (d) $\mathrm{FeO} /(\mathrm{FeO}+\mathrm{MgO})$ diagram from [21].

Some selected trace elements, $\mathrm{Sr}, \mathrm{Zr}, \mathrm{Co}, \mathrm{V}$ and $\mathrm{Cr}$ decrease with increasing $\mathrm{SiO}_{2}$ content. The elements $\mathrm{TiO}_{2}$, $\mathrm{P}_{2} \mathrm{O}_{5}, \mathrm{Sr}, \mathrm{Zr}$ and $\mathrm{Cr}$ show two trends which converge towards the most acidic terms (Fig. 5).Gabbro-diorite has high $\mathrm{Sr}$ (572-1146 ppm), Ba (927-2147 ppm) and medium to low $\mathrm{Rb}$ (75-145 ppm) values. It has average to high Cr (50-640ppm), $\mathrm{Ni}(40-190 \mathrm{ppm})$ and average Co $(8-46 \mathrm{ppm})$ contents. The $\mathrm{Zr}$ values (146-466ppm) are high. $\mathrm{Sr} / \mathrm{Y}$ (32-62.23), La/Yb (9.15-61.07) and $\mathrm{Nb} / \mathrm{Ta}(11.67-15.45)$ ratios are high. Basic enclaves have high $\mathrm{Sr}$ (574-706 ppm) and $\mathrm{Ba}$ (873-6333 ppm) concentrations. They have low levels of $\mathrm{Rb}$ (72-125 ppm). They are richer in $\mathrm{Cr}$ (430-1040 ppm), Ni (170-330 ppm) and Co (33-48 ppm) compared to gabbro-diorites and granites. Enclaves have high $\mathrm{Zr}$ contents (155-925 ppm). The Sr/Y (21.55-39.22), La/Yb (9.15-47) and $\mathrm{Nb} / \mathrm{Ta}(12.50-20)$ ratios are close to those of gabbro-diorites which are well above the crustal average.

The REE patterns normalized to the values of the primitive mantle are parallel to each other (Fig. 6) [22]-[23]. Gabbrodiorites are enriched more in REE ( $\Sigma \mathrm{REE}=132-436)$ than enclaves $(\Sigma R E E=134-207)$. The REE patterns are LREE enriched in gabbro-diorites $\left((\mathrm{La} / \mathrm{Sm})_{\mathrm{N}}=2.54-4.16\right)$ than the enclaves $\left((\mathrm{La} / \mathrm{Sm})_{\mathrm{N}}=1.76-3.06\right)$. The HREE are little differentiated in the two types $\left((\mathrm{Yb} / \mathrm{Dy})_{\mathrm{N}}=1.3-2.3\right.$ in the gabbro-diorites and (1.1-1.7 in the enclaves). The REE patterns show weak negative europium anomalies $\left(\mathrm{Eu} / \mathrm{Eu}^{*}=\right.$ $0.78-1.00)$. The multi-element normalized to the primitive mantle values diagrams (Fig. $5 \mathrm{~b}$ and $5 \mathrm{~d}$ ) show strong positive $\mathrm{Ba}$ and $\mathrm{K}$ anomalies in both rocks, whereas the enclaves show strong positive $\mathrm{Hf}-\mathrm{Zr}$ anomalies, and gabbro-diorites show negative $\mathrm{Hf}-\mathrm{Zr}$ anomalies in both elements. Negative U, Th, 
$\mathrm{Nb}$, Ta and $\mathrm{Ti}$ anomalies are observed in the gabbro-diorites and enclaves.
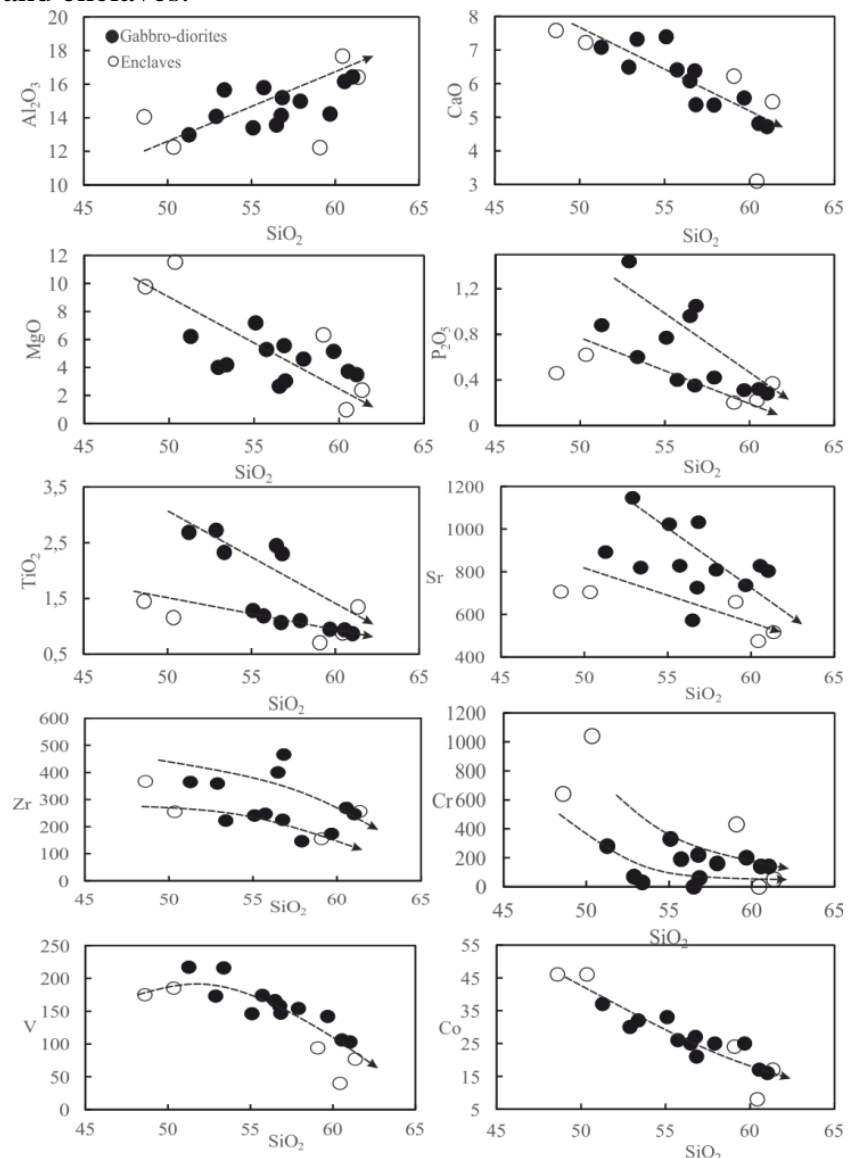

Fig. 5. Harker diagrams of some selected major and trace elements, sometimes showing two converging lines of evolution, indication of two sources and their mixture.

\section{DISCUSSION}

\section{A. Nature}

The gabbro-diorites of Bitkine and their associated enclaves are magnesian high-K calc-alkaline granitoids with shoshonite affinity. Their petrographic (rich amphibole + pyroxene + biotite $)$ and geochemical $((\mathrm{FeOt} /(\mathrm{FeOt}+\mathrm{MgO})=$ 0.51-0.85) characteristics are comparable to the ACG (Amphibole-rich Calc-alkaline Granitoids) type granitoids of [24]. The relatively high $\mathrm{Sr}(>300 \mathrm{ppm}), \mathrm{Ba}(>500 \mathrm{ppm})$ and relatively low $\mathrm{Rb}(110-219 \mathrm{ppm})$ contents indicate that they are high-Ba-Sr granitoids (high-Ba-Sr granitoids) of [25]. Some samples of gabbro-diorites and enclaves have $\mathrm{Sr} / \mathrm{Y}$ ratios greater than 40 suggesting an adakite characteristic. The Sr/Y vs Y diagram (Fig. 7) [26] shows that the Bitkine gabbro-diorites are typical calc-alkaline granitoids of active continental margins (Fig. 7b,c and d) [27]-[29], which is confirmed by the $\mathrm{Th} / \mathrm{Ta}$ vs $\mathrm{Yb}, \mathrm{Ce} / \mathrm{P}_{2} \mathrm{O}_{5}$ vs $\mathrm{Zr} / \mathrm{TiO}_{2}$ and $\mathrm{La} / \mathrm{Yb}$ vs Th/Yb diagrams (Fig.8) [27]-[30].
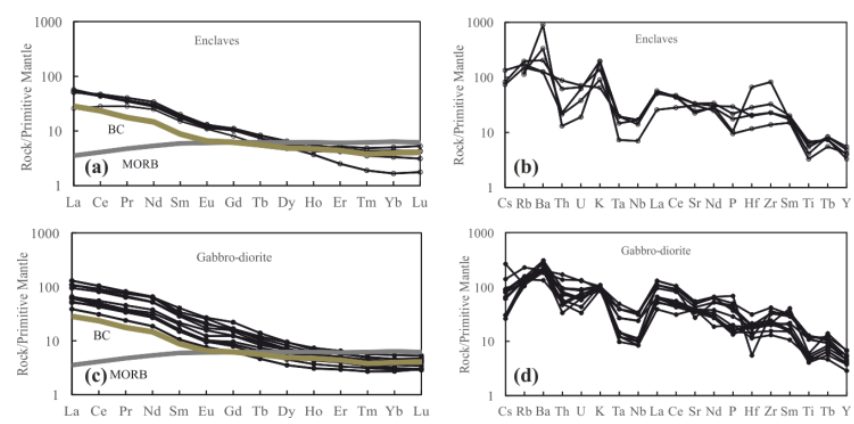

Fig. 6. REE normalized to primitive mantle diagram after [22]: (a) Enclaves pattern, (b) spider diagram of Enclaves, (c) Gabbro-diorites pattern, (d) Spider diagram of gabbro-diorites, values of Bulk crust (BC) and MORB are from [23]

\section{B. Origin}

The gabbro-diorites and enclaves are magnesian and shoshonite and occupy the domain of andesitic rocks in the $\mathrm{K}_{2} \mathrm{O}$ vs $\mathrm{SiO}_{2}$ diagram (Fig. 4b) [20].
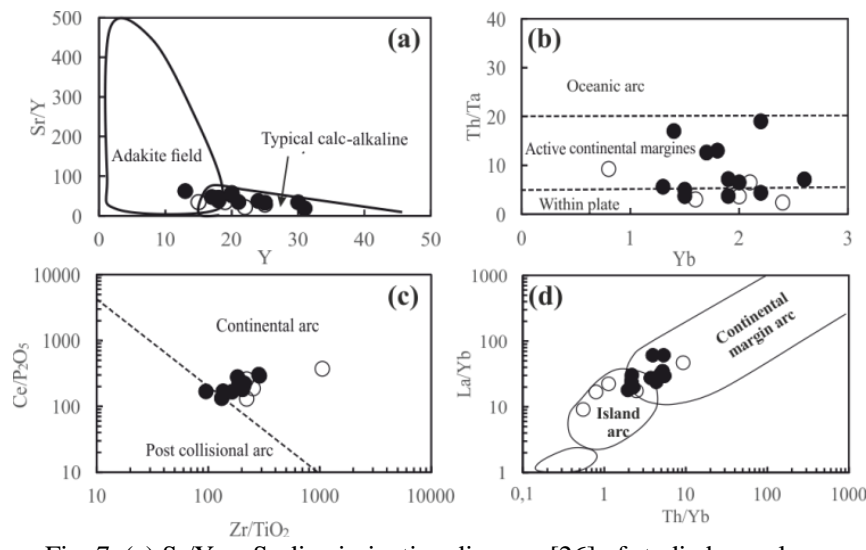

Fig. 7. (a) $\mathrm{Sr} / \mathrm{Y}$ vs $\mathrm{Sr}$ discrimination diagram [26] of studied samples, distribution of the samples in the geotectonic trace-element discrimination diagrams of [27] (b), [28](c) and [29](d).

They are characterized by relatively high contents of $\mathrm{MgO}$ (6-11\%), Ni (40-330ppm) and $\mathrm{Cr}$ (50-1040ppm), similar to those of rocks of mantle origin [30]. Their $\mathrm{Nb} / \mathrm{Ta}(12-20)$ and $\mathrm{Rb} / \mathrm{Cs}$ (11.31-126) ratios are closer to mantle values [22][30]. The negative Hf-Zr anomaly also underlines the mantle origin of the Bitkine gabbro-diorites (Fig. 6d).Indeed, in the diagrams $\mathrm{Nb} / \mathrm{Ta}$ vs $\mathrm{Th} / \mathrm{Yb}, \mathrm{Rb} / \mathrm{Cs}$ vs $\mathrm{Rb}$ and $\mathrm{Th} / \mathrm{Yb}$ vs $\mathrm{Nb} / \mathrm{Yb}$ (Fig. 8) [23]-[32], the gabbro-diorites and their enclaves are plotted between the MORB and the upper crust.

This intermediate position suggests that the gabbro-diorites and their enclaves are the result of a mixture of two magmas, one of mantle origin and the other of crustal origin, or of a mantle magma enriched by the material of the crust. Moreover, their position in the $\mathrm{Th} / \mathrm{Yb}$ vs. $\mathrm{Nb} / \mathrm{Yb}$ diagram (Fig. 8c) indicates that the evolution of this mantle magma was influenced by a component of the subduction zone. If the vector of fractional crystallization is significant (Fig. 9) [33][34], it remains that other phenomena have also impacted the differentiation of the original magma. Generally, the $\mathrm{Eu} / \mathrm{Eu}^{*}$ value decreases when the $\mathrm{SiO}_{2}$ content increases in a mantle magma that is differentiated by simple fractional crystallization. In gabbro-diorites and their enclaves, Eu/Eu* seems to be constant despite the fact that some samples cluster around two to three oblique lines underlining a differentiation by fractional crystallization (Fig. 8d). 

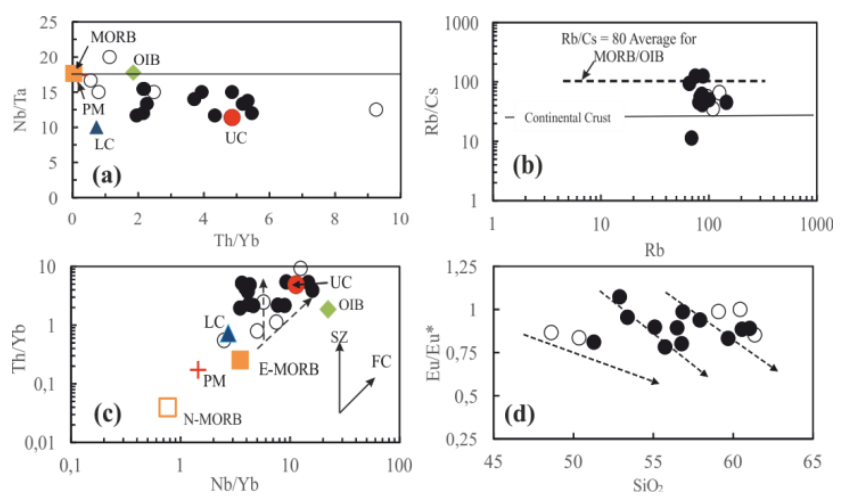

Fig. 8. Nb/Ta vs Th/Yb (a), Rb/Cs vs $\mathrm{Rb}$ (b) and $\mathrm{Th} / \mathrm{Yb}$ vs $\mathrm{Nb} / \mathrm{Yb}$ (c) diagrams showing the position of the studied samples in relation to the MORB and upper crust, MORB, OIB primitive mantle (PM), lower crust (LC), upper crust (UC) values are from [27] and[30]. Eu/Eu* vs $\mathrm{SiO}_{2}$ (d) diagram showing the complexity of the differentiation of magma.

The behavior of $\mathrm{Eu} / \mathrm{Eu}^{*}$ values in the diagram $\mathrm{Eu} / \mathrm{Eu}^{*}$ vs $\mathrm{SiO}_{2}$ (Fig. 8d) indicates that fractional crystallization is not the only process of differentiation of the magma of these rocks. Indeed, in the $\mathrm{Ba} / \mathrm{Nb}$ vs $\mathrm{Nb}$ diagram (Fig. 9a), the enclaves and some gabbro-diorite samples are arranged vertically and parallel to the $\mathrm{Ba} / \mathrm{Nb}$ axis, indicating the slab fluids enrichment of the magma [33]-[35].
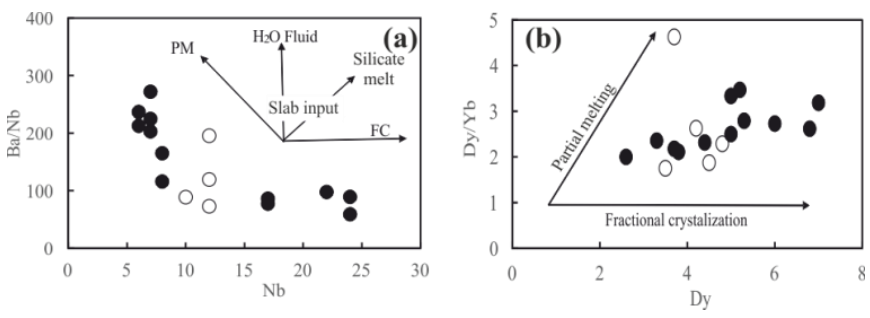

Fig. 9. $\mathrm{Nb}$ versus $\mathrm{Ba} / \mathrm{Nb}$ diagram [33] with sample distribution displaying trend consistent with a the fractional crystallization (FC) and slab fluid input process (a) and $\mathrm{Dy} / \mathrm{Yb}$ vs Dy diagram [34] showing two parallel trends of fractional crystallization (b).

The fractional crystallization process is further highlighted in the $\mathrm{Dy} / \mathrm{Yb}$ vs Dy diagram (Fig. 9b) [34] in which the samples are zoned around two horizontal lines. This arrangement confirms that the Bitkine rocks are derived from two magmas from different sources, a mantle source enriched by subduction zone fluids and a crustal source. Field data as well as geochemical data indicate that the two magmas evolved by fractional crystallization and subsequently underwent incomplete mixing as highlighted by the presence of swarms of microgranular enclaves (Fig. 3c and 3d).

\section{CONCLUSION}

The Bitkine gabbro-diorites and their enclaves have the composition of monzogabbro, monzodiorite, diorite, monzonite and syenite. They are high-K calc-alkaline, magnesian granitoids with shoshonite affinity. Their $\mathrm{Nb} / \mathrm{Ta}$, $\mathrm{Rb} / \mathrm{Cs}$ and $\mathrm{Th} / \mathrm{Yb}$ ratios suggest that they result from the crystallization of a magma of hybrid origin. The swarms of enclaves and magmatic breccias, as well as the development of two straight lines of evolution by certain major and trace elements, clearly show the existence of two magmas that have mixed together. These magmas occurred in an environment of active continental margin. The most probable source is a mantle enriched by the fluids of the subduction zone, whose partial melting produced a magma that initially evolved by fractional crystallization and during its ascent was contaminated by crustal material.

\section{ACKNOWLEDGMENT}

This article is part of the first author's PhD thesis. D.M is particularly grateful to the administration of the "Université Polytechnique de Mongo" for its support during field campaigns and multiple stays at the University of Dschang (Cameroon). Diontar Mbaihoudou thanks Dr. E. M. Fozing for reading the manuscript and his comments which helped to improve it. Thanks to the anonymous reviewers for their constructive contributions.

\section{REFERENCES}

[1] M., Abdelsalam, J.P., Liégeois, R.J., Stern. The Saharan Metacraton. Journal of African Earth Sciences, vol. 34, pp.119-136. 2002.

[2] J.P., Liégeois, M.G., Abdelsalam, N., Ennih, A., Ouabadi. Metacraton: nature, genesis and behavior. Gondwana Research 23, pp.220-237. 2013.

[3] J.L., Schneider, J.P., Wol. Carte géologique et cartes hydrogéologiques à 1/1500000 de la République du Tchad. Mémoire explicatif. 2vol. Documents du BRGM. 209p. Orléans (France). 1992.

[4] I., Kusnir, H.A., Moutaye. Ressources minérales du Tchad : une revue. Journal of African Earth Sciences, vol. 24, pp.549-562.1997.

[5] M.Y., Kasser. Evolution précambrienne de la région du Mayo- Kebbi (Tchad). Un segment de la chaîne panafricaine. Thèse Muséum National d'Histoire Naturelle de Paris, 217p. 1995.

[6] M., Isseini, A., Hamit, M., Abderamane. The tectonic and geological framework of the Mongo area, a segment of the Pan-African Guera Massif in Central Chad: evidences from field observations and remote sensing. Rev. Sci. Tchad, vol.1, pp.4-12. 2013.

[7] J.G., Shellnutt, N.H.T., Pham, W.D., Steven, M.W., Yeh, T.Y., Lee. Timing of collisional and post-collisional Pan-African Orogeny silicic magmatism in south-central Chad. Precambrian Research, vol. 301, pp.113-123. 2017

[8] P., Louis. Contribution géophysique à la connaissance géologique du bassin du lac Tchad. Bulletin ORSTOM, 42p.

[9] N.H.T., Pham, J.G., Shellnutt, M.W., Yeh, T.Y., Lee, T.-Y. A-type granites from the Guéra Massif, Central Chad: Petrology, geochemistry, geochronology, and petrogenesis. EGU General Assembly Conference Abstracts 19, 6211. 2017.

[10] J.P., Liégeois, R., Black, J., Navez, L., Latouche. Early and late PanAfrican orogenies in the Air assembly of terranes (Tuareg shield, Niger). Precambrian Research, vol. 68, pp.335-344. 1994.

[11] I.B., Suayah, J.S., Miller, B.V., Miller, T.M., Bayer, J.W., Rogers Tectonic significance of Late Neoproterozoic granites from the Tibesti massif in southern Libya inferred from $\mathrm{Sr}$ and $\mathrm{Nd}$ isotopes and $\mathrm{U}-\mathrm{Pb}$ zircon data. Journal of African Earth Science, vol. 44, pp.561570.2006

[12] R., Tchameni, A., Pouclet, J., Penaye, A.A., Ganwa, S.F., Toteu. Petrography and geochemistry of the Ngaoundéré Pan-African granitoids in Central North Cameroon: implications for their sources and geological setting. Journal of African Earth Science, vol. 44, pp.511-529. 2006

[13] N., Fezaa, J.P., Liégeois, N., Abdallah, E.H., Cherfouh, B., De Waele, O., Bruguier, A., Ouabadi. Late Ediacaran geological evolution (575$555 \mathrm{Ma}$ ) of the Djanet terrane, eastern Hoggar, Algeria, evidence for a Murzukian intracontinental episode. Precambrian Research, vol. 180, pp.299-327. 2010

[14] N.H.T., Pham, J.G., Shellnutt, M.W., Yeh, T.Y., Lee, T.-Y. Ediacaran juvenile continental crust formation within the Saharan Metacraton: evidence from the Guéra Massif, southern Chad. Geol. Soc. Taiwan Annu Meeting May 10th to 11th. 2017.

[15] N.H.T., Pham, J.G., Shellnutt, M.W., Yeh, Y., Iizuka. An Assessment of the Magmatic Conditions of Late Neoproterozoic Collisional and Post-collisional Granites Fromthe Guéra Massif, South-CentralChad. Front. Earth Sci. 8:318.doi: 10.3389/feart.2020.00318.2020. 
[16] E., Ferré, G., Gleizes, R., Caby. Obliquely convergent tectonics and granite emplacement in the Trans-Saharan belt of Eastern Nigeria: a synthesis. Precambrian Research, vol.114, pp.199-219. 2002.

[17] S.F., Toteu, J., Penaye, Y.H.P., Djomani. Geodynamic evolution of the Pan-African belt in central Africa with special reference to Cameroon. Canadian Journal of Earth Science, vol. 41, pp.73-85. 2004.

[18] A., Peccerillo, S.R., Taylor. Geochemistry of Eocene calc-alkaline volcanic rocks from the Kastamonu area, Northern Turkey. Contribution to Mineralogy and Petrology, vol. 58, pp.63-81. 1976.

[19] P.C., Rickwood. Boundary lines within petrologic diagrams which use oxides of major and minor elements. Lithos, vol. 22, pp.247-264. 1989.

[20] M.P., Roberts, J.D., Clemens. Origin of high-potassium, calc-alkaline, I-type granitoids. Geology, vol. 21, pp.825-828. 1993

[21] B.R., Frost, C.G., Barnes, W.J., Collins, R.J., Arculus, D.J., Ellis, C.D., Frost. A geochemical classification for granitic rocks. Journal of Petrology, vol. 42, pp.2033-2048. 2001.

[22] W.F. McDonough, S.S., Sun, A.E., Ringwood, E., Jagoutz, A.W., Hofmann. Potassium, rubidium, and cesium in the Earth and Moon and the evolution of the mantle of the Earth. Geochimica et Cosmochimica Acta, vol. 56, pp.1001-1012. 1992.

[23] W., Hofmann, K.P., Jochum, M., Seufert, W.M., White. Nb and Pb in oceanic basalts: new constraints on mantle evolution. Earth Planetary Science Letter, vol.79, pp.33-45. 1986.

[24] [24] B., Barbarin. A review of the relationships between granitoid types, their origins and their geodynamic environments. Lithos, vol.46, pp.605-626, 1999

[25] J., Tarney, C.E., Jones. Trace element geochemistry of orogenic igneous rocks and crustal growth models. Journal of the Geological Society of London, vol. 151, pp.855-868. 1994.

[26] M.J., Defant, M.S., Drummond. Derivation of some modern arc magmas by melting of young subducted lithosphere. Nature, vol. 347, pp.662-665. 1990 .

[27] M.P., Gorton, E.S., Schandl. From continents to island arcs: geochemical index of tectonic setting for arc-related and within-plate felsic o intermediate volcanic rocks. Can. Mineral, vol. 38, pp.10651073. 2000.

[28] D., Müller, D.I, Groves. Potassic Igneous Rocks and Associated GoldCopper Mineralization. 3rd edition. Springer-Verlag, Berlin (238 pp). 1997.

[29] K.C., Condie. Geochemical changes in basalts and andesites across the Archean Proterozoic boundary: identification and significance. Lithos vol.23, pp.1-18.1989.

[30] [30] S.S., Sun, W.F., McDonough. Chemical and isotopic systematic of oceanic basalts: implications for mantle composition and processes. Geological Society Special Publication, vol. 42, pp.313-345. 1989

[31] C.R., Stern, R., Kilian. Role of the subducted slab, mantle wedge and continental crust in the generation of adakites from the Austral Volcanic Zone. Contribution to Mineralogy and Petrology, vol. 123, pp.263-281. 1996.

[32] N.L., Green. Influence of slab thermal structure on basalt source regions and melting conditions: REE and HFSE constraints from the Garibaldi volcanic belt, northern Cascadia subduction system. Lithos vol. 87, pp.23-49. 2006.

[33] [33] E., Bourdon, J.P., Eissen, M., Monzier, C., Robin, H., Martin, J., Cotton, M., Hall. Adakite-like lavas from Antisana Volcano (Ecuador): evidence for slab melt metasomatism beneath the Andean North Volcanic Zone. Journal of Petrology, Vol. 43, pp.199-217. 2002.

[34] J., Ahmadian, F., Sarjoughian, D., Lentz, A., Esna-Ashari, M., Murata, H., Ozawa. Eocene K-rich adakitic rocks in the Central Iran: Implications for evaluating its $\mathrm{Cu}-\mathrm{Au}-\mathrm{Mo}$ metallogenic potential. Ore Geology Reviews, vol. 72, pp.323-342. 2016.

[35] M., Kwékam, P., Affaton, O., Bruguier, J.P., Liégeois, G., Hartmann, E., Njonfang. The pan-African kekem gabbro-norite (WestCameroon), U-Pb zircon age, geochemistry and $\mathrm{Sr}-\mathrm{Nd}$ isotopes: Geodynamical implication for the evolution of the Central African fold belt. Journal of African Earth Sciences, vol. 84, pp.70-88, 2013.

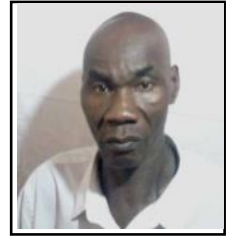

Diontar Mbaihoudou is a Master degrees holder in petrology of magmatic rocks.

M. Diontar Mbaihoudou is Lecturer at the "Université Polytechnique de Mongo" Chad He is also a Ph.D candidate at the University of Dschang, Cameroon.

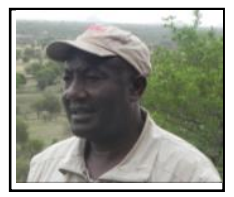

Pr. M Kwékam is a Ph.D holder in Magmatic petrology at the University of Yaoundé I, Cameroon,

Pr Kwékam is Associate Professor at the University of Dschang, Cameroon 